\author{
Dorota Paśko-Koneczniak \\ Uniwersytet Mikołaja Kopernika \\ Toruń
}

\title{
OSOBLIWOŚCI FUNKCJONOWANIA GWAR WYSPOWYCH (NA MARGINESIE BADAŃ ROSYJSKIEJ GWARY STAROOBRZĘDOWCÓW W OŚRODKU SUWALSKO- -AUGUSTOWSKIM I POLSKIEJ GWARY MIESZKAŃCÓW WIERSZYNY NA SYBERII)
}

Rosyjska gwara staroobrzędowców mieszkających w Polsce w ośrodku suwalsko-augustowskim ${ }^{1}$ i polska gwara mieszkańców Wierszyny na Syberii stanowią ciekawy obiekt badań nad funkcjonowaniem gwar wyspowych. W obydwu gwarach pod wpływem obcego otoczenia językowego zachodzą silne procesy interferencyjne, szczególnie na poziomie leksykalnym. Leksyka jest tym elementem języka $\mathrm{L}_{1}$, na który język otoczenia $\mathrm{L}_{2}$ oddziałuje najszybciej. Wybrane gwary wyspowe są ciekawym materiałem ilustracyjnym dla zachodzących zjawisk językowych, ponieważ występują one na analogicznych płaszczyznach języka w obydwu gwarach. Oderwanie od języka ogólnonarodowego i izolacja powodują identyczne zmiany w badanych gwarach, m.in. zapożyczanie słownictwa, kalkowanie, przełączanie kodu, hybrydyzację [por. Ananiewa 2007; Decyk 1995; Głuszkowski 2009, 2010; Глушковски 2010; Głuszkowski 2011; Grek-Pabisowa 1968, 1983; Гжибовски 2011; Гжибовски, Глушковски 2008; Paśko 2009, 2010, 2010a, 2011; Пасько 2011; Paśko-Koneczniak 2011a, 2011b]. Zjawiska tego typu są powszechne dla gwar wyspowych funkcjonujących w obcym otoczeniu językowym [por. Jankowiak 2009; Krawczyk 2007; Rieger, Masojć, Rutkowska 2006].

Iryda Grek-Pabisowa jako gwarę wyspową (wyspę gwarową) traktuje „gwarę pozostającą w otoczeniu innego języka, niemającą terytorialnego kontaktu ze swym językiem ogólnonarodowym" [Grek-Pabisowa 1983: 8]. Kazimierz Feleszko, badając kontakty języka polskiego i niemieckiego jako języków wyspowych na Bukowinie do 1939 r., również zwraca uwagę na aspekt geograficzny statusu obydwu badanych języków, a mianowicie

${ }^{1}$ Ośrodek suwalsko-augustowski obejmuje dwa skupiska: region suwalski i region augustowski, które nie różnią się od siebie zakresem i charakterem interferencji [Głuszkowski 2010: 179]. 
oddalenie od zamkniętych rodzimych obszarów [Feleszko (1987) 2002: 152]. Sytuacja wyspowa prowadzi do różnego rodzaju zmian językowych, szeroko rozumianej interferencji. Według Uriela Weinreicha interferencję należy pojmować jako przypadki odchyleń od normy w omawianych językach na skutek znajomości więcej niż jednego języka, czyli w wyniku kontaktu językowego [Weinreich (1953) 2000: 22; Feleszko (1987) 2002: 149; Paśko-Koneczniak 2011a: 45]. Sytuacja, w jakiej znajduje się gwara wyspowa, łączy się z sytuacją kontaktu językowego [Głuszkowski 2011: 29].

Staroobrzędowcy ${ }^{2}$, którzy osiedlali się na ziemiach polskich, poczynając od drugiej połowy XVII w., tworzyli swoiste enklawy, żyli w izolacji i nie mieli zbyt wielu okazji do kontaktu z polskojęzycznym otoczeniem, w którym byli mniejszością etniczno-religijną [Głuszkowski 2011: 28-29; Paśko-Koneczniak 2011a: 27]. Obecnie największe skupisko staroobrzędowców na terenie Polski znajduje się w dwóch wsiach powiatu augustowskiego, tj. w Gabowych Grądach i Borze, kilkanaście rodzin mieszka w Suwałkach i Augustowie ${ }^{3}$ Staroobrzędowcy są społecznością dwujęzyczną, w zależności od kontekstu socjolingwistycznego używają dwóch języków: rosyjskiej gwary i języka polskiego. Dwujęzyczność staroobrzędowców trudno jednoznacznie zaklasyfikować jako bilingwizm lub jako dyglosję. W przypadku badanej gwary mamy raczej do czynienia z pewną odmianą bilingwizmu, z tzw. bilingwizmem o charakterze dyglosyjnym [Paśko-Koneczniak 2011a: 43-45]. Rosyjska gwara jest używana w kontaktach z rodziną, z sąsiadami, natomiast w kontaktach z obcymi, z osobami stojącymi wyżej w hierarchii społecznej używa się języka polskiego. Sytuacja ta dotyczy praktycznie przedstawicieli socjolektu starszego pokolenia staroobrzędowców [Paśko-Koneczniak 2011a: 44]. W średnim i młodszym pokoleniu to język polski jest językiem o wyższym prestiżu i pełni bardzo ważną funkcję komunikatywną. Michał Głuszkowski zauważa, że „na początku XXI wieku staroobrzędowcy regionu suwalsko-augustowskiego $\mathrm{w}$ dalszym ciągu stanowią wyspę gwarową, choć wstąpienie Polski do Unii Europejskiej w 2004 r., a później przystąpienie do układu z Schengen, znoszącego kontrolę graniczną pod koniec 2007 r., znacząco ułatwiło kontakty ze starowiercami w krajach bałtyckich. Jednakże wieloletnia izolacja staroobrzędowców w Polsce od ich współwyznawców na Litwie, Łotwie i w Estonii sprawia, że jeszcze nie nastąpiło masowe ożywienie stosunków" [Głuszkowski 2011: 30].

Nieco inaczej wygląda sytuacja socjolingwistyczna gwary wyspowej wierszynian. Wierszyna to polska wieś na Syberii, założona w roku 1910 w wyniku masowej i dobrowolnej migracji ochotników z obszaru dawnego zaboru Małopolski i Zagłębia [Nowicka, Głowacka-Grajper 2003b: 10; Paśko-Koneczniak 2011b: 29]. Mieszkańcy Wierszyny żyli początkowo w izolacji społecznej i kulturowej, która wyrażała się głównie w ich negatywnym stosunku do małżeństw mieszanych, np. z Buriatami [Nowicka, Głowacka-Grajper

${ }^{2}$ Staroobrzędowcy mieszkający obecnie w Polsce są potomkami staroobrzędowców, którzy w drugiej połowie XVII w. nie przyjęli reform patriarchy Nikona i odłączyli się od Cerkwi prawosławnej. Prześladowani za wiarę, uciekali w głąb Rosji albo za granicę [Zielińska 1996: 9].

${ }^{3}$ Pojedyncze rodziny starowierskie zamieszkują m.in. miejscowości: Nowinka, Blizna, Szczebra, Białobrzegi, Wodziłki, Sztabinki, Sejny, Hołny Wolmera, Szury, Płociczno. 
2003c: 56-57; Paśko-Koneczniak 2011b: 29]. Izolacja terytorialna, społeczna i kulturowa była jedną z podstawowych przyczyn zachowania polskiej gwary wśród wierszynian [Nowicka, Głowacka-Grajper 2003c: 57]. Zdaniem Ewy Nowickiej i Małgorzaty Głowackiej-Grajper: „Buriaci stanowili element konserwujący polskość. Silna odmienność języka buriackiego, należącego do zupełnie innej rodziny językowej, w którym nie znajdowano ani leksykalnych, ani strukturalnych czy fonetycznych podobieństw, prowadziła do izolacji językowej" [Nowicka, Głowacka-Grajper 2003c: 57]. Z najnowszych badań ${ }^{4}$ wynika, że nastąpiło swoiste przełamanie izolacji, czego skutkiem jest nie tylko obecność rosyjskich elementów językowych w badanej gwarze, ale i hybrydyzacja kultury mieszkańców Wierszyny, przejawiająca się m.in. w obrzędach związanych z zaręczynami i małżeństwem, a także pogrzebem, w ludowych sposobach przewidywania pogody, tradycjach świątecznych i innych [Głuszkowski 2010: 90-91]. Wierszynianie są społecznością bilingwalną, posługują się polską gwarą będącą mieszaniną gwar z okolic, z których przybyli pierwsi osadnicy, i języka rosyjskiego [Głuszkowski 2009: 5-6; Paśko-Koneczniak 2011b: 30]. Na podstawie obserwacji językowych można zauważyć, że na co dzień po polsku porozumiewają się przedstawiciele starszego pokolenia i osoby w średnim wieku w rodzinach, w których oboje małżonkowie pochodzą z polskich rodzin [Głuszkowski 2009: 5-6; Paśko 2009: 23]. Wśród dzieci i młodzieży tylko nieliczne osoby znają język polski na poziomie komunikatywnym, a dosyć szeroko jest rozpowszechniona bierna znajomość polszczyzny. W młodszym pokoleniu jest sporo osób, które rozumieją język polski w bardzo wąskim zakresie [Głuszkowski 2009: 6]. Niewątpliwie młodsze pokolenie wierszynian na co dzień woli porozumiewać się w języku rosyjskim. Ewa Nowicka zaznacza, że społeczność polska w Wierszynie stanowi wyspę na oceanie rosyjskim [Nowicka 2011]. Gwara mieszkańców Wierszyny nie jest typową gwarą wyspową, ponieważ wielu jej mieszkańców ma kontakt z polskim językiem literackim dzięki wyjazdom do Polski, częstym wycieczkom z Polski do Wierszyny, a niektórzy ukończyli nawet studia w Polsce [Paśko 2009: 22]. Trudno jednoznacznie ustalić moment, w którym język rosyjski zaczął wypierać polską gwarę z poszczególnych sfer życia. Wpływ języka rosyjskiego na gwarę jest szczególnie widoczny w sferze słownictwa.

Tamara Lonngren podkreśla, że w przypadku gwar wyspowych obce otoczenie językowe ma dwojakie znaczenie, $\mathrm{z}$ jednej strony przyczynia się do zachowania swoistych cech gwarowych, z drugiej natomiast sprzyja przenikaniu elementów z języka otoczenia do gwary [Лённгрен 1994: 11]. W obydwu badanych gwarach proces przenikania obcych elementów zachodzi w tych samych sferach tematycznych. Iryda Grek-Pabisowa, prowadząc badania nad słownictwem rosyjskiej gwary staroobrzędowców w Polsce, wyróżniła kręgi tematyczne, w których odnotowała największą liczbę polonizmów. Najwięcej zapożyczeń z języka polskiego stwierdziła w słownictwie

${ }^{4}$ Badania gwary mieszkańców Wierszyny prowadzone były przez studentów, doktorantów i pracowników UMK w trakcie ekspedycji dialektologicznej na przełomie lipca i sierpnia 2008 r. Materiał zgromadzony został w postaci nagrań na dyktafonach cyfrowych. Wywiady najczęściej dotyczyły życia codziennego, historii, tradycji, rodziny i pracy. 
z zakresu administracji, kultury, zdrowia, szkoły, nazw zawodów, handlu, odzieży i wojska [Grek-Pabisowa 1983: 57; por. Paśko-Koneczniak 2011a: 100-102]. Gwary wyspowe odczuwają deficyt językowy spowodowany przede wszystkim rozwojem cywilizacyjno-kulturowym, rozwojem techniki, który pociąga za sobą brak nazw dla nowych desygnatów. Powstałe w ten sposób luki w zasobie leksykalnym gwary wyspowe uzupełniają przez zapożyczanie słownictwa z języka otoczenia. Każdy wyraz zapożyczony jest konkretnym, wyraźnym świadectwem oddziaływania języka otoczenia na gwarę [Paśko-Koneczniak 2011a: 83]. W rosyjskiej gwarze staroobrzędowców i w polskiej gwarze mieszkańców Wierszyny działają identyczne mechanizmy zapożyczania słownictwa z języków urzędowych (gwara staroobrzędowców czerpie nowe słownictwo z języka polskiego, natomiast gwara mieszkańców Wierszyny z języka rosyjskiego). Zapożyczane jest słownictwo z zakresu zdrowia, nazw zawodów, gospodarstwa domowego, oświaty, transportu, rolnictwa, które podlega w różnym stopniu procesom adaptacyjnym ${ }^{5}, \mathrm{np}$ :

\begin{tabular}{|c|c|c|}
\hline $\begin{array}{l}\text { Sfera } \\
\text { tematyczna }\end{array}$ & $\begin{array}{l}\text { Zapożyczenia z języka polskiego } \\
\text { do gwary staroobrzędowców }\end{array}$ & $\begin{array}{l}\text { Zapożyczenia z języka rosyjskiego do polskiej } \\
\text { gwary mieszkańców Wierszyny }\end{array}$ \\
\hline \multirow{2}{*}{ Zdrowie } & nerv'ovyj* (pol. nerwowy) & ń'ervnyj (ros. нервныцй) \\
\hline & ćlonža (pol. ciąża) & b’er'em'ena (ros. беременная) \\
\hline \multirow{5}{*}{$\begin{array}{c}\text { Nazwy } \\
\text { zawodów }\end{array}$} & l'ekarka (pol. lekarka) & vrac' (ros. врач) \\
\hline & ćleśla (pol. cieśla) & pł'otn'ik (ros. плотник) \\
\hline & krafc'ovaja (pol. krawcowa) & portn'ixa (ros. портниха) \\
\hline & prakur'atar (pol. prokurator) & prokur'or (ros. прокурор) \\
\hline & naučyćel (pol. nauczyciel) & prepodav'ac'el (ros. преподаватель) \\
\hline \multirow{3}{*}{$\begin{array}{c}\text { Gospodarstwo } \\
\text { domowe }\end{array}$} & l'ad'ufka (pol. lodówka) & xołoz'iln'ik (ros. холодильник) \\
\hline & pr'alka (pol.pralka) & sc'ir'alnaja mašlyna (ros. стиральная машина) \\
\hline & umyv'alka (pol. umywalka) & umyv'aln'ik (ros. умыьвальник) \\
\hline \multirow{3}{*}{ Oświata } & l'ekcyja (pol. lekcja) & ur'ok (ros. ypok) \\
\hline & ł'afka (pol. ławka) & p'arta (ros. napma) \\
\hline & vak'acji (pol. wakacje) & kan'ikuły (ros. каникульь) \\
\hline \multirow{2}{*}{ Transport } & samax'ot (pol. samochód) & mašl'yna (ros. мащuна) \\
\hline & paćlong (pol.pociag) & p'ojest (ros. nоезд) \\
\hline Rolnictwo & gaspad'arstva (pol. gospodarstwo) & xaz'ajstfo (ros. хозяйство) \\
\hline Handel & skl'ep (pol. sklep) & magaz'in (ros. магазин) \\
\hline
\end{tabular}

* Do zapisu wyrazów zapożyczonych zastosowano uproszczoną transkrypcję fonetyczną.

Opracowanie własne na podstawie analizy zgromadzonego materiału ${ }^{6}$.

${ }^{5}$ Zapożyczone leksemy mogą podlegać np. adaptacji fonetycznej, derywacyjnej, morfologicznej lub akcentuacyjnej [Paśko 2010; Paśko-Koneczniak 2011a: 84-97].

${ }^{6}$ Zgromadzony materiał pochodzi z nagrań: rosyjskiej gwary staroobrzędowców z ośrodka suwalsko-augustowskiego i polskiej gwary mieszkańców Wierszyny. 
Przytoczone przykłady wskazują na dynamikę zmian zachodzących w badanych gwarach wyspowych pod wpływem języków otoczenia. Analogiczną sytuację zapożyczania można również zaobserwować w innych gwarach mniejszości narodowych.

Oprócz procesu zapożyczania słownictwa żywymi procesami w gwarach wyspowych są również kalkowanie i hybrydyzacja [Paśko 2009, 2010a; Paśko-Koneczniak 2011a: 103-130]. Interesującym przykładem kalki syntaktycznej związanej z wyrażaniem relacji czasowych jest konstrukcja oznaczająca powtarzalność i częstotliwość. W rosyjskiej gwarze staroobrzędowców w celu oznaczenia regularnego powtarzania się czynności funkcjonuje konstrukcja typu: što + biernik rzeczownika [Гжибовски 2011: 51; Paśko-Koneczniak 2011a: 119]. W języku rosyjskim składniki oznaczające powtarzalność i częstotliwość wyrażane są przez konstrukcję składającą się z biernika rzeczowników z wyrazem кажdый. Konstrukcja ta odpowiada analogicznej konstrukcji w języku polskim co + mianownik (niekiedy biernik lub dopełniacz) [Bogusławski, Karolak 1970: 296]. Polska konstrukcja została zaadaptowana do gwary staroobrzędowców przez dosłowne kalkowanie i istnieje w postaci što + biernik, np. što ńeź'el'u (pol. co tydzień, ros. каждую неделю), što sub'otu (pol. со sobotę, ros. каждую субботу), što got (pol. co roku) [Paśko-Koneczniak 2011a: 119]. Z kolei mieszkańcy Wierszyny pod wpływem języka rosyjskiego dla oznaczenia powtarzalności i częstotliwości kalkują konstrukcję rosyjską, np. k'aždy v'ecur (pol. co wieczór, ros. каждый вечер), $\mathrm{k}^{\prime}$ ažde r'ano (pol. co rano, ros. каждое ympo), $\mathrm{k}^{\prime} \mathrm{aždy}$ rok (pol. co roku, ros. каждый год).

Interesującym czynnikiem wpływającym na stan gwary wyspowej jest fakt, że gwara istnieje wyłącznie w postaci mówionej ${ }^{7}$. W obydwu mniejszościach etnicznych działają zespoły ludowe - w społeczności staroobrzędowców folklorystyczny zespół Riabina, który wykonuje tradycyjne pieśni rosyjskie, a w Wierszynie tradycyjne pieśni polskie śpiewa zespół Jarzumbek. Gwary istnieją w postaci mówionej, teksty pieśni zapisywane są więc alfabetem, jaki obowiązuje dla języka otoczenia, tzn. staroobrzędowcy zapisują pieśni rosyjskie łacinką, a mieszkańcy Wierszyny do zapisu nie tylko pieśni polskich, ale również tekstów modlitw używają grażdanki [por. Paśko 2011].

Na podstawie obserwacji językowych i analizy materiału gwarowego można pokusić się o prognozę przyszłości badanych gwar. Niewątpliwie czynnikami scalającymi społeczność i jednocześnie odróżniającymi ją od otoczenia będą w obydwu przypadkach religia i język, aczkolwiek w przypadku mieszkańców Wierszyny religijność została zredukowana do minimum, a życie religijne skupia się zaledwie wokół kilku rodzin na około 400 mieszkańców wsi. Michał Głuszkowski zauważa, że „przez lata w wierszyńskiej społeczności znacznie spadło znaczenie podstawowych wyznaczników przynależności narodowej: religii i obyczajowości, a w młodszym i średnim

${ }^{7}$ W przypadku polskiej społeczności Wierszyny kilka osób potrafi pisać po polsku. 
pokoleniu - również języka. Wobec braku lub osłabienia tradycyjnych czynników powstrzymujących proces amalgamacji przedstawicieli mniejszości z otaczającym ich ogółem, zastanawiające jest utrzymanie własnej odrębności przez wierszyńskich Polaków" [Głuszkowski 2009: 13]. Wpływ języka rosyjskiego na zasób leksykalny wierszynian jest ogromny i powoduje wiele różnorodnych transformacji w gwarze. Analogiczne transformacje można zaobserwować w gwarze staroobrzędowców, $\mathrm{z}$ tą tylko różnicą, że wynikają one z wpływu polszczyzny. Na utrzymanie tudzież zanik języka mniejszości wpływa wiele czynników. Ograniczenie tradycyjnych sfer jego zastosowania, większy prestiż języka otoczenia, przejście na język otoczenia w sferze domowej (rodzinno-sąsiedzkiej), a przede wszystkim brak transmisji pokoleniowej prowadzą do zaniku języka ${ }^{8}$ [Głuszkowski 2011: 251]. W przypadku społeczności Wierszyny istnieje prawdopodobieństwo, że ich polszczyzna zaginie, ponieważ dla dzieci i młodzieży językiem prymarnym jest już rosyjski, a język polski znają tylko biernie [Пасько 2011: 79; Głuszkowski 2010: 94]. Z kolei w społeczności staroobrzędowców pomimo ograniczenia tradycyjnych sfer użycia rosyjskiej gwary „wciąż jednak wielu rodziców dba o międzypokoleniową transmisję języka przodków, także w otoczeniu polskojęzycznym" [Głuszkowski 2011: 270].

W przypadku gwar wyspowych największy wpływ języka otoczenia widoczny jest w ich zasobie leksykalnym i to właśnie słownictwo jest największą osobliwością gwar wyspowych, ponieważ każdy nowy element rzeczywistości znajduje swoje odzwierciedlenie w języku.

\section{BIBLIOGRAFIA}

A naniewa N., 2007, O polskich gwarach na Syberii: projekt badawczy, „Acta Baltico-Slavica", 31, s. 25-32.

Bogusławski A., Karolak S., 1970, Gramatyka rosyjska w ujęciu funkcjonalnym, Warszawa. Decyk W., 1995, Próba opisu polskiej gwary we wsi Wierszyna, „Poradnik Językowy”, 8, s. 20-31. Feleszko K., (1987) 2002, O kontaktach języków polskiego i niemieckiego jako języków wyspowych (na przykładzie Bukowiny do 1939 r.), [w:] Fele szko K., Bukowina moja miłość. Język polski na Bukowinie Karpackiej do 1945 roku, t. 1, red. A. Żor, Warszawa, s. 149-160.

Głuszkowski M., 2009, Obraz własny mieszkańców Wierszyny - polskiej wsi na Syberii na tle historii ich miejscowości. Na podstawie tekstów pisanych oraz ustnych relacji wierszynian, „Literatura Ludowa”, 2, s. 3-17.

Głuszkowski M., 2010, Wierszyna, polska wieś na Syberii. Hybrydyzacja kultury a hybrydyzacja języka, [w:] Kuligowski W. (red.), Nowe języki. Studia z zakresu kreolizacji języków i kultur, Wrocław, s. 85-94.

${ }^{8}$ Analizę procesu zaniku i utrzymywania się języka na podstawie badań wspólnoty staroobrzędowców w Pensylwanii przeprowadził Jeffrey Holdeman. Informacja za [Głuszkowski 2011: 251]. 
Głuszkowski M., 2011, Socjologiczne i psychologiczne uwarunkowania dwujęzyczności staroobrzędowców regionu suwalsko-augustowskiego, Toruń.

Głuszkowski M., Grzybowski S. (red.), 2010, Staroobrzędowcy za granica, Toruń.

Grek-Pabisowa I., 1968, Rosyjska gwara starowierców w województwach olsztyńskim i białostockim, Wrocław-Warszawa-Kraków-Gdańsk.

Grek-Pabisowa I., 1983, Słownictwo rosyjskiej wyspy gwarowej staroobrzędowców mieszkających w Polsce. Rozwój i stan dzisiejszy, Wrocław-Warszawa-Kraków-Gdańsk-Łódź.

Jankowiak M., 2009, Gwary białoruskie na Łotwie w rejonie krasławskim, Warszawa.

Krawczyk A., 2007, Zapożyczenia leksykalne w sytuacji wielojęzyczności. Ukrainizmy i rusycyzmy w gwarze Maćkowiec na Podolu, Warszawa.

Kuligowski W. (red.), 2010, Nowe języki. Studia z zakresu kreolizacji języków i kultur, Wrocław.

Nowicka E., 2011, „Losy Wierszyny, czyli z wyspy na wyspę” (referat wygłoszony na Międzynarodowej Konferencji Naukowej „Słowiańskie wyspy językowe i kulturowe” w Toruniu 15-16 IX 2011, zorganizowanej przez Instytut Filologii Słowiańskiej UMK).

Nowicka E., Głowacka-Grajper M. (red.), 2003a, Wierszyna z bliska i z oddali: obrazy polskiej wsi na Syberii, Kraków.

Nowicka E., Głowacka-Grajper M., 2003b, Wprowadzenie. Wierszyna jako pole badań, [w:] Nowicka E., Głowacka-Grajper M. (red.), Wierszyna z bliska i z oddali: obrazy polskiej wsi na Syberii, Kraków, s. 9-12.

Nowicka E., Głowacka-Grajper M., 2003c, Polskość zastygła. Spojrzenie antropologa na Wierszyne, [w:] Nowicka E., Głowacka-Grajper M. (red.), Wierszyna z bliska i z oddali: obrazy polskiej wsi na Syberii, Kraków, s. 33-70.

Paśko D., 2009, O kalkach słowotwórczych w polszczyźnie mieszkańców Wierszyny na Syberii, „Slavia Meridionalis”, 9, s. 21-28.

Paśko D., 2010, Adaptacja akcentuacyjna zapożyczeń z języka polskiego do rosyjskiej gwary staroobrzędowców w ośrodku augustowskim, [w:] Głuszkowski M., Grzybowski S. (red.), Staroobrzędowcy za granica, Toruń, s. 181-188.

Paśko D. 2010a, Hybrydy językowe w rosyjskiej gwarze staroobrzędowców w ośrodku augustowskim, [w:] Kuligowski W. (red.), Nowe języki. Studia z zakresu kreolizacji języków i kultur, Wrocław, s. 95-102.

Paśko D., 2011, Powiązania między językiem polskim a wyznaniem katolickim wśród bilingwalnej społeczności wierszynian na Syberii, [w:] Golachowska E., Zielińska A. (red.), Wokót religii i jej języka. Konstrukcje i destrukcje tożsamości, Warszawa, s. 113-120.

Paśko-Koneczniak D., 2011a, Wpływ polszczyzny na zasób leksykalny rosyjskiej gwary staroobrzędowców na Suwalszczyźnie, Toruń.

Paśko-Koneczniak D., 2011b, Wpływ języka rosyjskiego na zasób leksykalny polskiej gwary mieszkańców Wierszyny na Syberii, „Acta Baltico-Slavica”, 35, s. 29-36.

Rieger J., Masojć I., Rutkowska K. (red.), 2006, Słownictwo polszczyzny gwarowej na Litwie, Warszawa.

Zielińska A., 1996, Wielojęzyczność staroobrzędowców mieszkających w Polsce, Warszawa.

Вайн райх У., (1953) 2000, Языковые контакты. Состояние и проблемы исследования, пер. Ю. А. Жлуктенко, Благовещенск. 
Глушковски М., 2010, Территориальная разновидность говора польских старообрядиев (На примере избранных идиолектов), [w:] Głuszkowski M., Grzybowski S. (red.), Staroobrzędowcy za granica, Toruń, s. 171-180.

Гжибовски С., 2011, Русский островной говор в польском языковом окружении, [w:] Гжибовски С., Хорев В.А., Волос М. (ред.), 2011, Русско-польские языковые, литературные и культурные контакты, Москва, с. 45-59.

Гжибовски С., Глушковски М., 2008, Социолингвистическая ситуация старообрядиев в деревнях Габове Гронды и Бур (Польша), [w:] Касаткин Л. Л. (ред.), 2008, Русские старообряды. Язык. Культура. История, Москва, с. 200-214.

Гжибовски С., Хорев В. А., Волос М. (ред.), 2011, Русско-польские языковые, литературные и культурные контакты, Москва.

Касат к ин Л. Л. (ред.), 2008, Русские старообряды. Язык. Культура. История, Москва. Лён нгрен Т., 1994, Лексика русских старообрядческих говоров (на материале, собранном в Латгалии и Житомирщине), Uppsala.

Пасько Д., 2011, Польский островной говор дер. Вершина в Сибири, [w:] Гжибовск и С., Хорев В.А., Волос М. (ред.), Русско-польские языковые, литературные и культурные контакты, Москва, с. 72-80.

PECULIARITIES OF THE FUNCTIONING OF ISLAND DIALECTS (ON THE MARGINS OF RESEARCH INTO THE RUSSIAN DIALECT OF THE OLD BELIEVERS IN THE SUWAŁKI-AUGUSTÓW REGION AND THE POLISH DIALECT OF THE INHABITANTS OF VERSHINA IN SIBERIA)

\section{SUMMARY}

The article deals with the functioning of island dialects: the Russian dialect of the Old Believers from the Suwałki-Augustów region and the Polish dialect of the inhabitants of Vershina in Siberia. The former functions in the Polish-language environment, and the latter in the Russian-language environment. The speakers of island dialects do not have any contact with their nationwide languages. The foreign language environment influences the linguistic condition of island dialects to a considerable degree. On the one hand, it contributes to cultivating distinct features of the dialect; on the other, it facilitates the process in which elements of the surrounding language permeate the dialect. The major peculiarity of the island dialect is its vocabulary. It is also the most rapidly changing linguistic element. Each and every aspect of reality will sooner or later be reflected in language. Island dialects 'fill' their linguistic gap by means of borrowing words from the surrounding language. Both dialects studied in this article borrow lexical items in such fields as health, jobs and professions, household management, education, transportation, and farming, which then at various degrees are subject to adaptation processes. 


\section{ОСОБЕННОСТИ ФУНКЦИОНИРОВАНИЯ ОСТРОВНЫХ ГОВОРОВ (ПО ПОВОДУ ИССЛЕДОВАНИЙ РУССКОГО ГОВОРА СТАРООБРЯДЦЕВ В СУВАЛЬСКО-АВГУСТОВСКОМ РЕГИОНЕ И ПОЛЬСКОГО ГОВОРА ЖИТЕЛЕЙ ДЕР. ВЕРШИНА В СИБИРИ)}

\section{РЕЗЮME}

Статья посвящена функционирванию двух островных говоров: русского говора старообрядцев, проживающих в сувальско-августовском регионе и польского говора жителей деревни Вершина в Сибири. Говор старообрядцев находится в польском языковом окружении, а говор вершининцев в русском языковм окружении. Говоры островного характера не имеют территориального контакта со своим общенародным языком. Иноязычное окружение в большой степени влияет на языковое состояние островного говора. С одной стороны оно способствует сохранению своеобразия определённого диалекта, а с другой, взаимопроникновению элементов одного языка в диалект другого. Особенностью островных говоров является прежде всего их лексика. Лексика - это тот пласт языка, который подвергается самым быстрым изменениям. В случае островных говоров лексический запас пополняется заимствованиями, которые касаются обычно повседневной жизни. В исследуемых говорах заимствования затронули бытовую и хозяйственную лексику, а также названия профессий, названия связанные со здоровьем, транспортом, торговлей, школой.

Słowa kluczowe: Wierszyna, staroobrzędowcy, gwara wyspowa, dwujęzyczność, zapożyczenie językowe, kalka językowa.

Key words: Vershina, Old Believers, island dialect, bilingualism, borrowing, calque.

Ключевые слова: Вершина, старообрядцы, островной говор, двуязычие, языковое заимствование, языковая калька. 